Editorial

\title{
Electrical Power and Energy Systems for Transportation Applications
}

\author{
Paul Stewart ${ }^{1, *}$ and Chris Bingham ${ }^{2}$ \\ 1 Institute for Innovation in Sustainable Engineering, Lonsdale House, Derby DE1 3EE, UK \\ 2 School of Engineering, University of Lincoln, Brayford Pool, Lincoln LN6 7TS, UK; cbingham@lincoln.ac.uk \\ * Correspondence: pstewart@pesri.net
}

Received: 11 July 2016; Accepted: 13 July 2016; Published: 14 July 2016

This book contains the successful invited submissions [1-25] to a Special Issue of Energies on the subject area of "Electrical Power and Energy Systems for Transportation Applications".

Electrical power and energy systems are at the forefront of application developments in, for example, more-electric and all-electric aircraft, electric and hybrid road vehicles, and marine propulsion applications. The associated hardware, technologies, and control methods are crucial to achieving critical global targets in energy efficiency, low-carbon, and low-emissions operations. The greatest challenges occur when we combine new technologies at large-scale and often complex system levels.

Topics of interest for the call included, but were not limited to:

- Novel Electrical Power Systems architectures and technologies;

- Energy vectors, integration with renewables, power and energy dense machines, converters and energy storage;

- Air, land, and sea vehicles; electrical propulsion and actuation for land, sea, and air vehicles;

- Electrical Machines, Drives, Systems, and Applications-AC and DC machines and drives;

- Multiscale systems modeling; remote monitoring and diagnosis;

- Power Electronic Systems - Converters and emerging technologies;

- Modeling simulation and control, reliability and fault tolerance, safety critical operation;

- Electrical Power Generation Systems-Modeling and simulation of electrical power systems;

- Load management; power quality; distribution reliability; distributed and islanded power systems, sensor networks, communication and control;

- Electrical Power Systems Modeling and Control-Modeling and control methodologies and applications;

- Intelligent systems; optimization and advanced heuristics; adaptive systems; robust control.

Response to our call was excellent, with the following statistics:

- Submissions: (101);

- Publications: (25);

- Rejections: (76);

- Article Types: Review Article (0); Research Article (25);

Authors' geographical distribution (published papers):

- China (16)

- Belgium (3)

- $\quad$ Spain (2) 
- $\quad$ Korea (2)

- Germany (2)

Published submissions inform the broad spectrum of technologies interfacing energy with transport and fall into four general areas of Renewables and Transmission, Generators, Batteries, and Electric Vehicles, as exemplified in Figure 1.

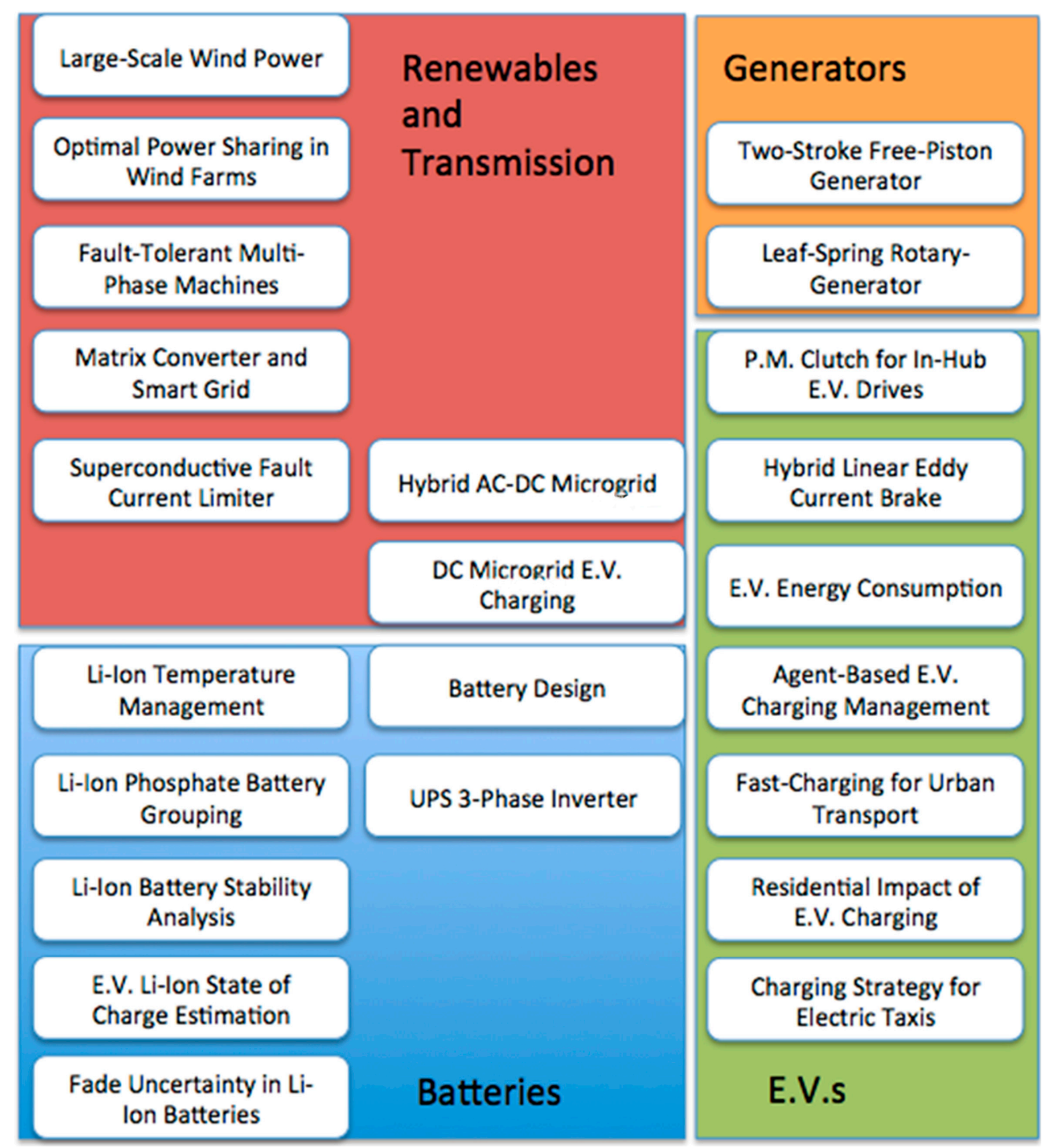

Figure 1. The broad spectrum of published submissions.

We found the task of editing and selecting papers for this collection to be both stimulating and rewarding. We would also like to thank the staff and reviewers for their efforts and input.

\section{References}

1. Zhang, Y.; Li, M.; Kang, Y. PID Controller Design for UPS Three-Phase Inverters Considering Magnetic Coupling. Energies 2014, 7, 8036-8055. [CrossRef]

2. Long, B.; Jeong, T.W.; Deuk Lee, J.; Jung, Y.C.; Chong, K.T. Energy Management of a Hybrid AC-DC Micro-Grid Based on a Battery Testing System. Energies 2015, 8, 1181-1194. [CrossRef]

3. Yang, Y.; Zhang, W.; Niu, L.; Jiang, J. Coordinated Charging Strategy for Electric Taxis in Temporal and Spatial Scale. Energies 2015, 8, 1256-1272. [CrossRef] 
4. Leemput, N.; Geth, F.; Van Roy, J.; Olivella-Rosell, P.; Driesen, J.; Sumper, A. MV and LV Residential Grid Impact of Combined Slow and Fast Charging of Electric Vehicles. Energies 2015, 8, 1760-1783. [CrossRef]

5. Liu, W.; Ge, R.; Lv, Q.; Li, H.; Ge, J. Research on a Small Signal Stability Region Boundary Model of the Interconnected Power System with Large-Scale Wind Power. Energies 2015, 8, 2312-2336. [CrossRef]

6. Kordonis, A.; Takahashi, R.; Nishihara, D.; Hikihara, T. The Three-Phase Power Router and Its Operation with Matrix Converter toward Smart-Grid Applications. Energies 2015, 8, 3034-3046. [CrossRef]

7. Hua, Y.; Xu, M.; Li, M.; Ma, C.; Zhao, C. Estimation of State of Charge for Two Types of Lithium-Ion Batteries by Nonlinear Predictive Filter for Electric Vehicles. Energies 2015, 8, 3556-3577. [CrossRef]

8. Shi, L.-W.; Zhou, B. Comparative Study of a Fault-Tolerant Multiphase Wound-Field Doubly Salient Machine for Electrical Actuators. Energies 2015, 8, 3640-3660. [CrossRef]

9. Olivella-Rosell, P.; Villafafila-Robles, R.; Sumper, A.; Bergas-Jané, J. Probabilistic Agent-Based Model of Electric Vehicle Charging Demand to Analyse the Impact on Distribution Networks. Energies 2015, 8, 4160-4187. [CrossRef]

10. Locment, F.; Sechilariu, M. Modeling and Simulation of DC Microgrids for Electric Vehicle Charging Stations. Energies 2015, 8, 4335-4356. [CrossRef]

11. Rogge, M.; Wollny, S.; Sauer, D.U. Fast Charging Battery Buses for the Electrification of Urban Public Transport-A Feasibility Study Focusing on Charging Infrastructure and Energy Storage Requirements. Energies 2015, 8, 4587-4606. [CrossRef]

12. Xue, S.; Gao, F.; Sun, W.; Li, B. Protection Principle for a DC Distribution System with a Resistive Superconductive Fault Current Limiter. Energies 2015, 8, 4839-4852. [CrossRef]

13. Lee, J.; Sung, W.; Choi, J.-H. Metamodel for Efficient Estimation of Capacity-Fade Uncertainty in Li-Ion Batteries for Electric Vehicles. Energies 2015, 8, 5538-5554. [CrossRef]

14. Cai, W.; Gu, C.; Hu, X. Analysis and Design of a Permanent Magnet Bi-Stable Electro-Magnetic Clutch Unit for In-Wheel Electric Vehicle Drives. Energies 2015, 8, 5598-5612. [CrossRef]

15. Ma, F.; Zhao, C.; Zhang, F.; Zhao, Z.; Zhang, S. Effects of Scavenging System Configuration on In-Cylinder Air Flow Organization of an Opposed-Piston Two-Stroke Engine. Energies 2015, 8, 5866-5884. [CrossRef]

16. Zheng, Y.; Yang, J.; Hu, Z.; Zhou, M.; Li, G. Credibility Theory-Based Available Transfer Capability Assessment. Energies 2015, 8, 6059-6078. [CrossRef]

17. Rothgang, S.; Rogge, M.; Becker, J.; Sauer, D.U. Battery Design for Successful Electrification in Public Transport. Energies 2015, 8, 6715-6737. [CrossRef]

18. Ran, X.; Miao, S.; Wu, Y. Improved Adaptive Droop Control Design for Optimal Power Sharing in VSC-MTDC Integrating Wind Farms. Energies 2015, 8, 7100-7121. [CrossRef]

19. Kou, B.; Jin, Y.; Zhang, L.; Zhang, H. Characteristic Analysis and Control of a Hybrid Excitation Linear Eddy Current Brake. Energies 2015, 8, 7441-7464. [CrossRef]

20. Li, X.; Song, K.; Wei, G.; Lu, R.; Zhu, C. A Novel Grouping Method for Lithium Iron Phosphate Batteries Based on a Fractional Joint Kalman Filter and a New Modified K-Means Clustering Algorithm. Energies 2015, 8, 7703-7728. [CrossRef]

21. Yuan, S.; Wu, H.; Ma, X.; Yin, C. Stability Analysis for Li-Ion Battery Model Parameters and State of Charge Estimation by Measurement Uncertainty Consideration. Energies 2015, 8, 7729-7751. [CrossRef]

22. Zhang, Y.; Zuo, Z.; Liu, J. Numerical Analysis on Combustion Characteristic of Leaf Spring Rotary Engine. Energies 2015, 8, 8086-8109. [CrossRef]

23. Liao, R.; Hu, E.; Yang, L.; Yuan, Y. Space Charge Behavior in Paper Insulation Induced by Copper Sulfide in High-Voltage Direct Current Power Transformers. Energies 2015, 8, 8110-8120. [CrossRef]

24. Goutam, S.; Timmermans, J.-M.; Omar, N.; Bossche, P.V.; Van Mierlo, J. Comparative Study of Surface Temperature Behavior of Commercial Li-Ion Pouch Cells of Different Chemistries and Capacities by Infrared Thermography. Energies 2015, 8, 8175-8192. [CrossRef]

25. De Cauwer, C.; Van Mierlo, J.; Coosemans, T. Energy Consumption Prediction for Electric Vehicles Based on Real-World Data. Energies 2015, 8, 8573-8593. [CrossRef]

(C) 2016 by the authors; licensee MDPI, Basel, Switzerland. This article is an open access article distributed under the terms and conditions of the Creative Commons Attribution (CC-BY) license (http://creativecommons.org/licenses/by/4.0/). 